\title{
Teknik Bagging Dan Boosting Pada Algoritma CART Untuk Klasifikasi Masa Studi Mahasiswa
}

\author{
Ahmad Rusadi Arrahimi ${ }^{1)}$, Muhammad Khairi Ihsan ${ }^{2)}$, Dwi Kartini ${ }^{3)}$, \\ Mohammad Reza Faisal ${ }^{4)}$, Fatma Indriani ${ }^{5)}$ \\ ${ }^{12) 334) 5)}$ Program Studi Ilmu Komputer FMIPA ULM \\ J1. A. Yani Km 36, Banjarbaru, Kalimantan Selatan \\ 1)ahmadrusadi@ulm.ac.id \\ 2)khairiihsan@gmail.com \\ 3) dwikartini@ulm.ac.id \\ 4) reza.faisal@gmail.com \\ 5) f.indriani@ulm.ac.id
}

\begin{abstract}
Abstrak
Data mahasiswa yang ada pada sistem informasi akademik selalu mengalami peningkatan setiap tahunnya. Data yang terkumpul dapat diolah menggunakan data mining untuk mendapatkan pengetahuan baru. Penulis berusaha menambang data mahasiswa untuk mengklasifikasi masa studi tepat waktu atau tidak tepat waktu. Data yang ada dianalisis menggunakan algoritma CART dengan teknik bagging dan algoritma CART dengan teknik boosting. Hasil klasifikasi dengan menggunakan data testing sejumlah 49 data, yaitu pada algoritma CART dengan teknik bagging 13 data (26,531\%) masuk ke dalam klasifikasi tepat waktu dan 36 data $(73,469 \%)$ masuk ke dalam klasifikasi tidak tepat waktu. Pada algoritma CART dengan teknik boosting 16 data $(32,653 \%)$ masuk ke dalam klasifikasi tepat waktu dan 33 data $(67,347 \%)$ masuk ke dalam klasifikasi tidak tepat waktu. Nilai accuracy klasifikasi masa studi mahasiswa menggunakan algoritma CART sebesar 79,592\%, algoritma CART denga teknik bagging sebesar 81,633\%, dan algoritma CART dengan teknik boosting sebesar $87,755 \%$. Dalam penelitian ini, algoritma CART dengan teknik boosting memiliki nilai accuracy yang paling baik.
\end{abstract}

Kata Kunci: Masa Studi, Klasifikasi, CART, Bagging, Boosting.

\begin{abstract}
Undergraduate Students data in academic information systems always increases every year. Data collected can be processed using data mining to gain new knowledge. The author tries to mine undergraduate students data to classify the study period on time or not on time. The data is analyzed using CART with bagging techniqu, and CART with boosting technique. The classification results using 49 testing data, in the CART algorithm with bagging techniques 13 data $(26.531 \%)$ entered into the classification on time and 36 data $(73.469 \%)$ entered into the classification not on time. In the CART algorithm with boosting technique 16 data $(32,653 \%)$ entered into the classification on time and 33 data (67,347\%) entered into the classification not on time. The accuracy value of the classification of study period of undergraduate students using the CART algorithm is $79.592 \%$, the CART algorithm with bagging technique is $81.633 \%$, and the CART algorithm with boosting technique is $87.755 \%$. In this study, the CART algorithm with boosting technique has the best accuracy value.
\end{abstract}

Keywords: Study Period, Classification, CART, Bagging, Boosting 


\section{PENDAHULUAN}

Data mahasiswa yang ada pada sistem informasi akademik setiap tahun mengalami peningkatan. Data yang terkumpul dapat dilakukan klasifikasi salah satunya dengan algoritma CART. Data yang didapatkan terdapat ketidakseimbangan data yang berarti salah satu kelas memiliki jumlah lebih sedikit dibandingkan dengan kelas lain (Chao, Liu, \& Ding, 2013). Pendekatan yang dapat dilakukan untuk menangani data tidak seimbang adalah dengan memasangkan metode ensamble misalnya bagging dan boosting (Yap et al., 2014). Bagging dan boosting berhasil meningkatkan akurasi dari hasil klasifikasi data buatan maupun sebenarnya (Liang \& Zhang, 2011). Hasil yang serupa juga didapat oleh Prasetio dan Pratiwi (2015) dan penelitian Bisri dan Wahono (2015) yang menerapkan metode adaboost sebagai metode boosting.

Berdasarkan uraian di atas, maka perlu adanya penelitian tentang teknik bagging dan boosting pada algorima CART untuk klasifikasi masa studi mahasiswa berdasarkan nilai IP dan banyak SKS yang diambil semester 1 sampai semester 4 .

\section{TINJAUAN PUSTAKA}

\subsection{Literatur Terdahulu}

Beberapa penelitian terdahulu yang berhubungan dengan penelitian yang dilakukan adalah jurnal oleh Nasution, Djahara dan Zamsuri (2015) yang menerapkan algoritma Nä̈ve Bayes dalam penentuan kelulusan dengan melibatkan atribut jenis kelamin, asal sekolah, program studi, IP semester satu sampai lima, IPK, dan target kelulusan. Dari penelitian ini dihasilkan akurasi terbaik sebesar 76,001\% kemudian setelah menggunakan atribut terpilih akurasi meningkat menjadi 76,67\%.

Jurnal oleh Salmu dan Solichin (2017) menggunakan atribut jenis kelamin, pendapatan ayah, pendidikan ibu, IP semester satu sampai empat, jumlah SKS yang diambil pada semester satu sampai empat dengan akurasi 80,72\% dengan menggunakan algoritma Nä̈ve Bayes.

Jurnal oleh Yamasari et al (2017) yang bertujuan untuk meningkatkan kinerja klasifikasi prestasi belajar mahasiswa yang bermasalah pada ketidaktepatan kelas. Metode yang digunakan Simple CART, Randam Forest, Decision Stump, dan J-48. Hampir semua metode klasifikasi yang digunakan menunjukan peningkatan akurasi kecuali Metode Random Forest.

\subsection{Classification and Regression Tree}

Classification and Regression Tree (CART) adalah salah satu algoritma decision tree. CART dikembangkan untuk melakukan analisis klasifikasi pada variable respon baik yang nominal, ordinal, maupun kontinu. CART menghasilkan suatu pohon klasifikasi jika variable responnya kategorik dan menghasilkan pohon regresi jika variable responnya kontinu. Tujuan utama $C A R T$ untuk mendapatkan suatu kelompok data yang akurat sebagai penciri dari suatu pengklasifikasian (Timofeev, 2004).

Menurut Lewis (2000), CART mempunyai beberapa kelebihan yaitu hasilnya lebih mudah diintreprestasikan, lebih akurat dan lebih cepat perhitungannya, selain itu CART bisa diterapkan untuk himpunan data yang mempunyai jumlah besar, variabel yang sangat banyak dengan skala variabel campuran melalui prosedur pemilahan biner.

Menurut Susanto dan Suryadi (2010) langkah-langkah algoritma CART adalah:

a. Menyusun candidate split yang dilakukan terhadap seluruh variabel predictor.

b. Memberikan penilaian keseluruhan calon cabang mutakhir dengan menghitung besaran $\Phi(\mathrm{s} \mid \mathrm{t})$.

c. Menentukan cabang yang memiliki kesesuaian $\Phi(\mathrm{s} \mid \mathrm{t})$. Setelah noktah keputusan tidak ada lagi, CART dihentikan.

Kesesuaian $\Phi(\mathrm{s} \mid \mathrm{t})$ dari calon cabang s pada noktaah keputusan t, didefiniskan sebagai persamaan i-vi berikut :

$\Phi(\mathrm{s} \mid \mathrm{t})=2 P_{L} P_{R} Q(s \mid t)$

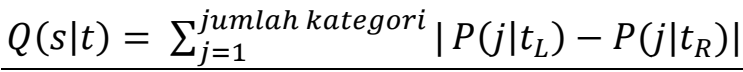


$\mathrm{t}_{\mathrm{L}}=$ Cabang kiri dari noktah keputusan $\mathrm{t}$

$t_{R}=$ cabang kanan dari noktah keputusan $t$

$P_{L}=\frac{\text { calon cabang kiri } t_{L}}{\text { data latihan }}$

$P\left(j \mid t_{L}\right)=\frac{j \text { calon cabang kiri } t_{L}}{\text { noktah keputusant }}$

$P_{R}=\frac{\text { calon cabang kanan } t_{R}}{\text { data latihan }}$

$\left(j \mid t_{R}\right)=\frac{j \text { calon cabang kanan } t_{R}}{\text { noktah keputusant }}$

\subsection{Bagging}

Bagging (bootstrap aggregating), menggunakan subdataset (bootstrap) untuk menghasilkan set pelatihan L (learning). L melatih dasar belajar menggunakan prosedur pembelajaran yang tidak stabil, dan kemudian, selama pengujian, mengambil rata-rata. Noise yang tinggi mempengaruhi klasifikasi baru yang dihasilkan, sehingga menyebabkan miss-classification (Prasetio \& Pratiwi, 2015). Bagging berguna untuk membangun pengklasifikasi menjadi lebih baik bila pada pengamatan kumpulan data latih yang terdapat noise (Alfaro, Gámez, \& García, 2013). Skema teknik bagging dapat dilihat pada Gambar 1.

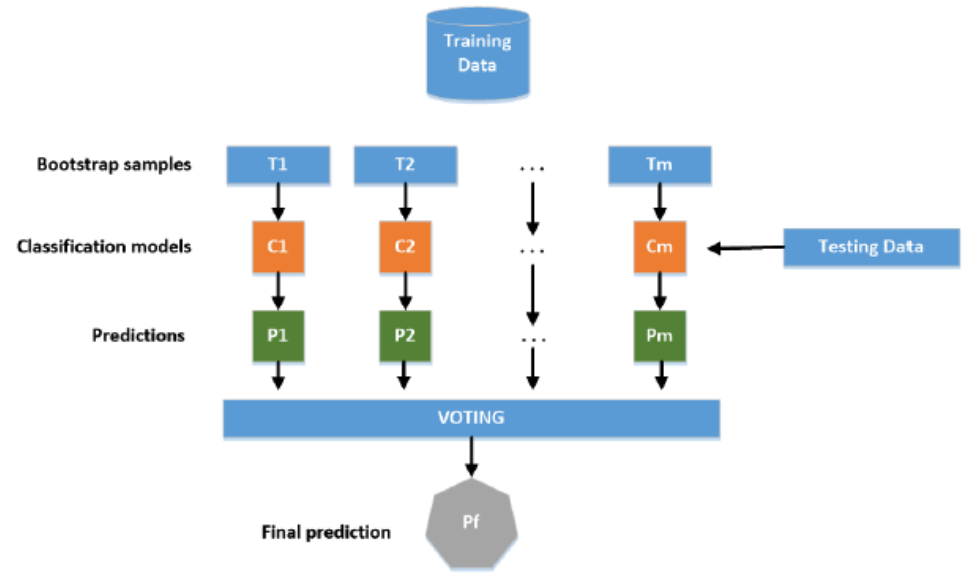

Gambar 1. Skema teknik bagging (Faisal, 2016)

\subsection{Boosting}

Algoritma boosting adalah algoritma iteratif yang memberikan bobot yang berbeda pada distribusi training data pada setiap iterasi. Setiap iterasi boosting menambahkan bobot pada contoh-contoh kesalahan klasifikasi dan menurunkan bobot pada contoh klasifikasi yang benar, sehingga secara efektif dapat merubah distribusi pada data training (S. Kotsiantis, Kanellopoulos, \& Pintelas, 2006). Metode Boosting (AdaBoost) yang diusulkan (S. B. Kotsiantis \& Pintelas, 2009) dengan selective costing ensemble dapat menjadi solusi yang lebih efektif untuk masalah class imbalance dan memungkinkan untuk meningkatkan identifikasi dari class minoritas yang sulit serta menjaga kemampuan klasifikasi dari class mayoritas. Pendekatan untuk mengatasi masalah tersebut dapat dilakukan dengan beberapa metode (Weiss, McCarthy, \& Zabar, 2007) yaitu over-sampling, under-sampling, dan cost-sensitive. Adapun skema teknik boosting dapat dilihat pada Gambar 2. 


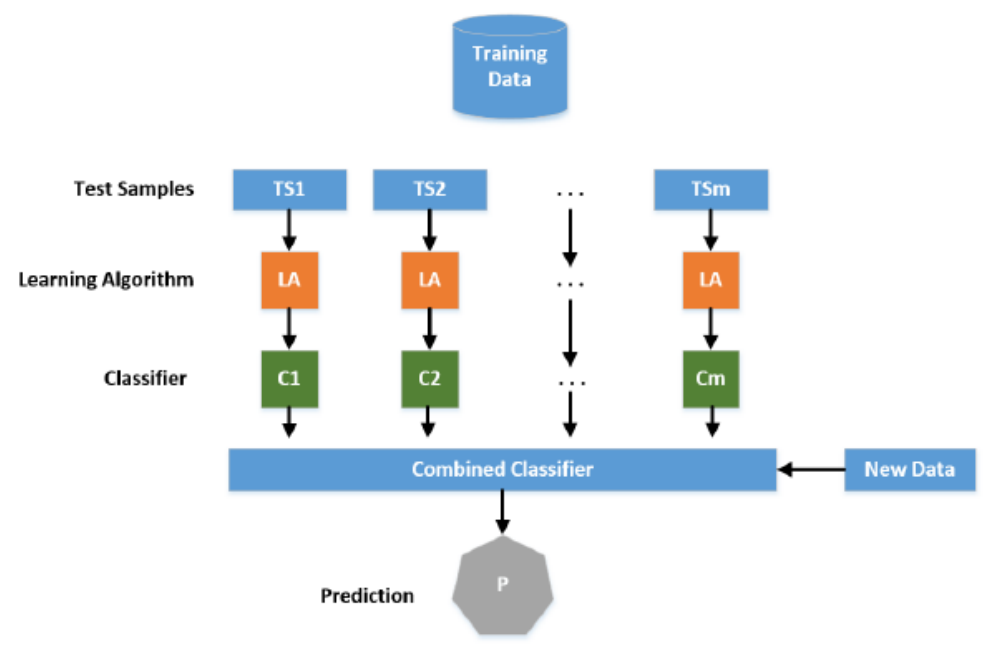

Gambar 2. Skema teknik boosting (Faisal, 2016)

\section{METODE PENELITIAN}

\subsection{Pencarian Literatur}

Literatur diperoleh dari uku-buku maupun referensi tentang masa studi mahasiswa, data mining, algoritma CART, teknik bagging dan boosting.

\subsection{Pengumpulan Data}

Data akademik mahasiswa dan data alumni mahasiswa Program Studi Ilmu Komputer FMIPA Universitas Lambung Mangkurat 2009-2014 yang diperoleh dari UPT PPTIK Universitas Lambung Mangkurat Banjarbaru.

\subsection{Pengolahan Data}

Data yang digunakan dalam penelitian ini diolah dengan menerapkan prinsip Knowledge Discovery in Database (KDD) yang meliputi tahapan sebagai berikut yang dapat dilihat pada Gambar 3.

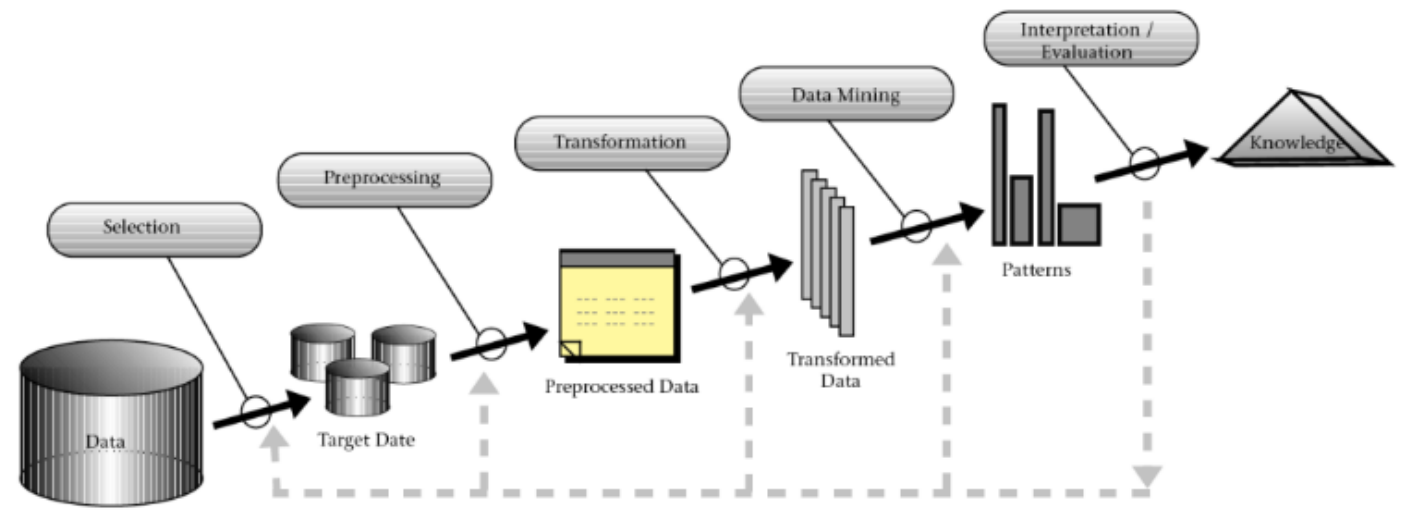

Gambar 3. Knowledge discovery in database

\section{PEMBAHASAN}

\subsection{Data Selection}

Data yang digunakan berasal dari database Sistem Informasi Akademik di Program Studi Ilmu Komputer FMIPA ULM. Atribut yang digunakan yaitu, NIM, IP semester satu sampai empat, jumlah sks yang diambil pada semester satu sampai empat, dan lama studi. 


\subsection{Pre-processing/Cleaning}

Data yang dihapus sebanyak empat data dikarenakan terdapat nilai kosong pada atribut. Data yang telah melalui tahap cleaning dapat dilihat pada Tabel 1 .

Tabel 1. Data yang di-cleaning

\begin{tabular}{|c|c|c|c|c|c|c|c|c|c|c|}
\hline \multirow{2}{*}{ No } & \multirow{2}{*}{ NIM } & \multicolumn{4}{|c|}{ SKS Semester } & \multicolumn{4}{|c|}{ IP Semester } & \multirow{2}{*}{$\begin{array}{c}\text { Masa Studi } \\
\text { (Semester) }\end{array}$} \\
\hline & & 1 & 2 & 3 & 4 & 1 & 2 & 3 & 4 & \\
\hline 1 & MAHASISWA 205 & 9 & - & 10 & 13 & 2,17 & - & 1,85 & 1,96 & 13 \\
\hline 2 & MAHASISWA 701 & - & - & 16 & 23 & - & - & 3,50 & 3,33 & 4 \\
\hline 3 & MAHASISWA 61 & 16 & 3 & 10 & 8 & 2,53 & 0,00 & 2,25 & 2,94 & 13 \\
\hline 4 & MAHASISWA 238 & 16 & 9 & - & 21 & 3,03 & 3,61 & - & 2,81 & 14 \\
\hline
\end{tabular}

\subsection{Transformation}

Data diubah menjadi bentuk yang sesuai sehingga dapat dilakukan proses data mining. Pada Lama masa studi ditentukan bahwa untuk 8 dan 9 semester masuk dalam kelas "Tepat Waktu" yang ditulis kelas klasifikasi "A" dan untuk di atas 9 semester masuk dalam kelas "Tidak Tepat Waktu" yang ditulis kelas klasifikasi "B".

Data yang telah ditransformasi dibagi menjadi dua bagian data, yaitu data training dan data testing. Data training berjumlah 146 data yang terdiri dari mahasiswa angkatan 2009-2011 dan data testing berjumlah 49 data yang terdiri dari mahasiswa angkatan 2012-2014.

\subsection{Data Mining}

\subsubsection{Algoritma CART}

Pertama-tama menyusun seluruh variabel yang menjadi calon cabang (candidate split) yang ada pada data training. Daftar calon cabang dapat dilihat pada Tabel 2.

Tabel 2. Daftar calon cabang

\begin{tabular}{|c|c|c|}
\hline & Calon Cabang Kiri & Calon Cabang Kanan \\
\hline $\begin{array}{l}\text { IP Semester } 1, \\
\ldots \text {, } \\
\text { SKS Semester } 4\end{array}$ & $\begin{array}{l}\text { IPS1<=1,31 } \\
\ldots<=\ldots \\
\text { SKS4 }<=23\end{array}$ & $\begin{array}{l}\text { IPS } 1>1,31 \\
\ldots>\ldots \\
\text { SKS4 > } 23\end{array}$ \\
\hline
\end{tabular}

Kemudian menghitung nilai calon cabang untuk probabilitas setiap cabang $\mathrm{P}_{\mathrm{L}}$ dan $\mathrm{P}_{\mathrm{R}}$. Untuk calon cabang kiri IPS $1 \leq 1,31$ yang memenuhi ada 1 data dan calon cabang kanan IPS $2>1,31$ yang memenuhi ada 145 data, maka dapat dilhitung $\mathrm{P}_{\mathrm{L}}$ dan $\mathrm{P}_{\mathrm{R}}$ sebagai berikut.

$\mathrm{P}_{\mathrm{L}}=\frac{1}{146}=0,006849$

$\mathrm{P}_{\mathrm{R}}=\frac{145}{146}=0,993151$

Setelah mendapatkan nilai $\mathrm{P}_{\mathrm{L}}$ dan $\mathrm{P}_{\mathrm{R}}$ maka selanjutnya menghitung $\mathrm{P}\left(\mathrm{j} \mid \mathrm{t}_{\mathrm{L}}\right)$ dan $\mathrm{P}\left(\mathrm{j} \mid \mathrm{t}_{\mathrm{R}}\right)$ untuk kelas A dan kelas B. Jumlah $\mathrm{P}\left(\mathrm{j} \mid \mathrm{t}_{\mathrm{L}}\right)$ untuk semua kelas harus sama dengan jumlah data yang memenuhi calon cabang kiri $\mathrm{P}_{\mathrm{L}}$ dan jumlah $\mathrm{P}\left(\mathrm{j} \mid \mathrm{t}_{\mathrm{R}}\right)$ untuk semua kelas juga harus sama dengan jumlah data yang memenuhi calon cabang kanan $\mathrm{P}_{\mathrm{R}}$. Pada $\mathrm{P}\left(\mathrm{j} \mid \mathrm{t}_{\mathrm{L}}\right)$ A tidak memiliki data dan $\mathrm{P}\left(\mathrm{j} \mid \mathrm{t}_{\mathrm{L}}\right)$ B memiliki 1 data. Pada $\mathrm{P}\left(\mathrm{j} \mid \mathrm{t}_{\mathrm{R}}\right)$ A memiliki 48 data dan $\mathrm{P}\left(\mathrm{j} \mid \mathrm{t}_{\mathrm{R}}\right)$ B memiliki 97 data.
$\mathrm{P}\left(\mathrm{j} \mid \mathrm{t}_{\mathrm{L}}\right) \mathrm{A}=\frac{0}{1}=0$
$\mathrm{P}\left(\mathrm{j} \mid \mathrm{t}_{\mathrm{R}}\right) \mathrm{A}=\frac{48}{145}=0,33$
$\mathrm{P}\left(\mathrm{j} \mid \mathrm{t}_{\mathrm{L}}\right) \mathrm{B}=\frac{1}{1}=1$
$P\left(j \mid t_{R}\right) B=\frac{97}{145}=0,67$

Kemudian menghitung nilai $\mathrm{Q}(\mathrm{s} \mid \mathrm{t})$ dan kesesuaian $\Phi(\mathrm{s} \mid \mathrm{t})$ sebagai berikut.

$$
\begin{aligned}
\mathrm{Q}(\mathrm{s} \mid \mathrm{t}) & =\left|\mathrm{P}\left(\mathrm{j} \mid \mathrm{t}_{\mathrm{L}}\right) \mathrm{A}-\mathrm{P}\left(\mathrm{j} \mid \mathrm{t}_{\mathrm{R}}\right) \mathrm{A}\right|+\left|\mathrm{P}\left(\mathrm{j} \mid \mathrm{t}_{\mathrm{L}}\right) \mathrm{B}-\mathrm{P}\left(\mathrm{j} \mid \mathrm{t}_{\mathrm{R}}\right) \mathrm{B}\right| \\
& =|0-0,33|+|1-0,67| \\
& =0,33+0,33 \\
& =0,66
\end{aligned}
$$




$$
\begin{aligned}
\Phi(\mathrm{s} \mid \mathrm{t}) & =2 P_{L} P_{R} \mathrm{Q}(\mathrm{s} \mid \mathrm{t}) \\
& =2 \times 0,006849 \times 0,993151 \times 0,66 \\
& =0,01
\end{aligned}
$$

Kemudian menghitung $\mathrm{P}_{\mathrm{L}}, \mathrm{P}_{\mathrm{R}}, \mathrm{P}\left(\mathrm{j} \mid \mathrm{t}_{\mathrm{L}}\right), \mathrm{P}\left(\mathrm{j} \mid \mathrm{t}_{\mathrm{R}}\right)$, nilai $\mathrm{Q}(\mathrm{s} \mid \mathrm{t})$, dan kesesuaian $\Phi(\mathrm{s} \mid \mathrm{t})$ dengan cara yang sama untuk semua calon cabang yang ada. Kesesuaian (goodness) $\Phi(\mathrm{s} \mid \mathrm{t})$ yang paling

\begin{tabular}{|c|c|c|c|c|c|c|c|c|c|c|c|c|}
\hline & \multicolumn{6}{|c|}{ IP Semester 1} & & \multicolumn{5}{|c|}{ SKS Semester 4} \\
\hline & 1,31 & 1,69 & 1,71 & 1,79 & 1,83 & 1,86 & $\ldots$ & 19 & 20 & 21 & 22 & 23 \\
\hline $\mathrm{P}_{\mathrm{L}}$ & 0,01 & 0,01 & 0,02 & 0,03 & 0,03 & 0,04 & $\ldots$ & 0,23 & 0,27 & 0,47 & 0,63 & 0,68 \\
\hline$P_{R}$ & 0,99 & 0,99 & 0,98 & 0,97 & 0,97 & 0,96 & $\ldots$ & 0,77 & 0,73 & 0,53 & 0,37 & 0,32 \\
\hline$P\left(j \mid t_{L}\right)-A$ & 0 & 0 & 0,33 & 0,25 & 0,2 & 0,17 & $\ldots$ & 0,03 & 0,05 & 0,13 & 0,17 & 0,22 \\
\hline$P\left(j \mid t_{L}\right)-B$ & 1 & 1 & 0,67 & 0,75 & 0,8 & 0,83 & $\ldots$ & 0,97 & 0,95 & 0,87 & 0,83 & 0,78 \\
\hline$P\left(j \mid t_{R}\right)-A$ & 0,33 & 0,33 & 0,33 & 0,33 & 0,33 & 0,34 & $\ldots$ & 0,42 & 0,43 & 0,51 & 0,59 & 0,57 \\
\hline$P\left(j \mid t_{R}\right)-B$ & 0,67 & 0,67 & 0,67 & 0,67 & 0,67 & 0,66 & $\ldots$ & 0,58 & 0,57 & 0,49 & 0,41 & 0,43 \\
\hline $\mathrm{Q}(\mathrm{s} \mid \mathrm{t})$ & 0,66 & 0,67 & 0,01 & 0,16 & 0,27 & 0,34 & $\ldots$ & 0,78 & 0,77 & 0,75 & 0,84 & 0,69 \\
\hline$\Phi(\mathrm{s} \mid \mathrm{t})$ & 0,01 & 0,02 & 0 & 0,01 & 0,02 & 0,03 & $\ldots$ & 0,08 & 0,09 & 0,1 & & 0,3 \\
\hline
\end{tabular}
tinggi dipilih menjadi cabang. Adapun hasil perhitungan dapat dilihat pada Tabel 3.

Tabel 3. Tabel perhitungan $\mathrm{P}_{\mathrm{L}}, \mathrm{P}_{\mathrm{R}}, \mathrm{P}\left(\mathrm{j} \mid \mathrm{t}_{\mathrm{L}}\right), \mathrm{P}\left(\mathrm{j} \mid \mathrm{t}_{\mathrm{R}}\right), \mathrm{Q}(\mathrm{s} \mid \mathrm{t})$, dan $\Phi(\mathrm{s} \mid \mathrm{t})$

Hasil perhitungan kesesuaian $\Phi(\mathrm{s} \mid \mathrm{t})$ menunjukkan bahwa calon cabang tertinggi nilai besarannya adalah 0,42 , yaitu cabang kiri SKS Semester $2 \leq 21$ dan cabang kanan SKS Semester $2>21$, maka calon cabang ini dipilih menjadi root node. Kemudian cabang yang laiinya akan terus dihitung dengan cara yang sama menggunakan iterasi selanjutnya sampai dengan maksimal tiga kedalaman. Berikut pohon keputusan yang dihasilkan setelah dilakukan iterasi dengan maksimal tiga kedalaman dapat dilihat pada Gambar 4.

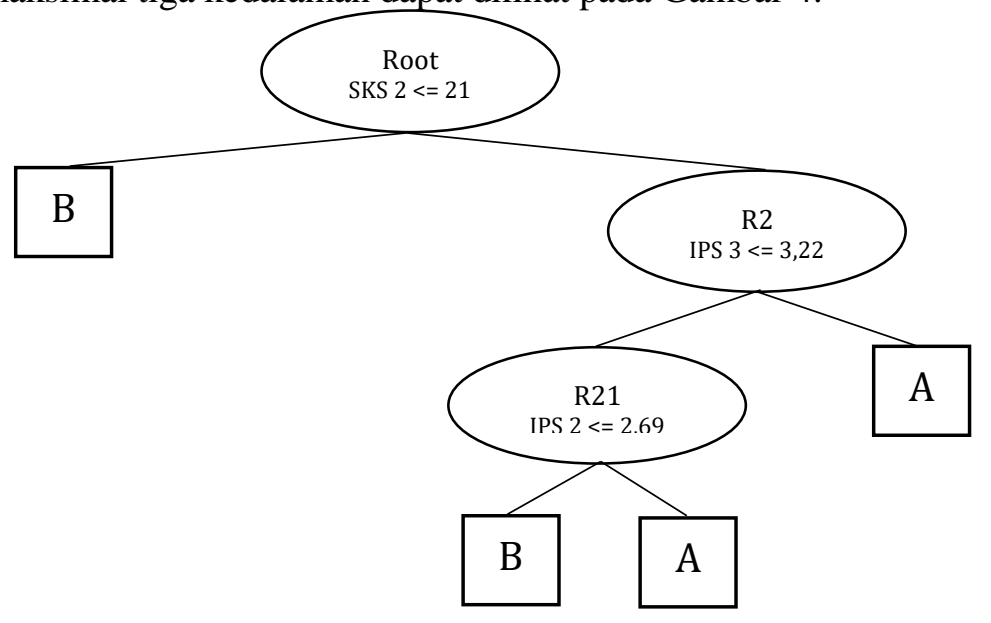

Gambar 4. Pohon keputusan algoritma $C A R T$

Setelah selelsai melakukan perhitungan algoritma CART, maka dilakukan percobaan untuk mengetahuan hasil klasfiakasi pada data testing. Hasil klasifikasi dapat dilihat pada Tabel 4.

Tabel 4. Hasil klasifikasi untuk data testing menggunakan algoritma CART

\begin{tabular}{cccccccccccc}
\hline \multirow{2}{*}{ No } & \multirow{2}{*}{ NIM } & \multicolumn{4}{c}{ IP Semester } & \multicolumn{4}{c}{ SKS Semester } & Kelas & Kelas \\
& & $\mathbf{1}$ & $\mathbf{2}$ & $\mathbf{3}$ & $\mathbf{4}$ & $\mathbf{1}$ & $\mathbf{2}$ & $\mathbf{3}$ & $\mathbf{4}$ & Aktual & CART \\
\hline 1 & MAHASISWA 3 & 3,16 & 3,17 & 2,92 & 3,12 & 16 & 12 & 18 & 21 & $\mathrm{~B}$ & $\mathrm{~B}$ \\
2 & MAHASISWA 4 & 3,16 & 2,57 & 2,75 & 3,24 & 19 & 21 & 20 & 21 & $\mathrm{~B}$ & $\mathrm{~B}$ \\
3 & MAHASISWA 6 & 3,07 & 2,62 & 2,66 & 3,25 & 22 & 21 & 16 & 16 & $\mathrm{~B}$ & $\mathrm{~B}$ \\
$\ldots$ & $\ldots$ & $\ldots$ & $\ldots$ & $\ldots$ & $\ldots$ & $\ldots$ & $\ldots$ & $\ldots$ & $\ldots$ & $\ldots$ & $\ldots$ \\
49 & MAHASISWA 214 & 3,59 & 3,69 & 3,76 & 3,83 & 22 & 24 & 23 & 24 & $\mathrm{~A}$ & $\mathrm{~A}$ \\
\hline
\end{tabular}




\subsubsection{Algoritma CART dengan Teknik Bagging}

Data training dibagi menjadi 10 bagging yang setiap data pada bagging diambil secara acak dari data training awal dan jumlahnya sama dengan jumlah data pada data training awal. Setiap bagging dilakukan perhitungan algoritma CART yang kemudian menghasilkan satu pohon keputusan pada setiap bagging. Pada proses data mining menggunakan algorima CART dengan teknik bagging ini menghasilkan sebanyak 10 pohon keputusan yang berbeda-beda.

Setelah mendapatkan 10 pohon keputusan, langkah selanjutnya adalah mengklasifikasikan data testing ke dalam setiap bagging yang berisi algoritma CART. Penentuan klasifikasi akhir dengan cara voting menggunakan klasifikasi kelas yang paling banyak muncul pada data testing dalam 10 bagging tersebut. Hasil klasifikasi dapat dilihat pada Tabel 5.

Tabel 5. Hasil klasifikasi data testing menggunakan algoritma CART dengan teknik bagging

\begin{tabular}{|c|c|c|c|c|c|c|c|c|c|c|c|c|}
\hline \multirow[b]{2}{*}{ No } & \multirow[b]{2}{*}{ NIM } & \multicolumn{10}{|c|}{ Bagging } & \multirow{2}{*}{$\begin{array}{c}\text { Kelas } \\
\text { Prediksi } \\
\text { Bagging }\end{array}$} \\
\hline & & 1 & 2 & 3 & 4 & 5 & 6 & 7 & 8 & 9 & 10 & \\
\hline 1 & MAHASISWA 3 & $\mathrm{~B}$ & $\mathrm{~B}$ & A & B & B & A & $\mathrm{B}$ & B & B & B & $\mathrm{B}$ \\
\hline 2 & MAHASISWA 4 & B & B & A & B & B & A & B & A & B & A & B \\
\hline 3 & MAHASISWA 6 & $\mathrm{~B}$ & B & B & B & B & B & B & A & B & $\mathrm{B}$ & B \\
\hline $\begin{array}{l}\cdots \\
49\end{array}$ & MAHASISWA 214 & A & A & A & A & A & $\begin{array}{l}\cdots \\
\mathrm{B}\end{array}$ & A & A & A & $\dddot{A}$ & A \\
\hline
\end{tabular}

\subsubsection{Algoritma CART dengan Teknik Boosting}

Pertama-tama data training diberi bobot dengan bobot awal

$D_{I}(i)=\frac{1}{146}$

$D_{l}(i)=0,006849$

Kemudian dilakukan pengambilan data secara acak menjadi boosting 1 yang diambil dari data training. Data boosting 1 dapat dilihat pada Tabel 6.

Tabel 6. Data pada boosting 1

\begin{tabular}{ccccccccccc}
\hline \multirow{2}{*}{ No } & \multirow{2}{*}{ NIM } & \multicolumn{4}{c}{ IP Semester } & \multicolumn{3}{c}{ SKS Semester } & \multirow{2}{*}{$\begin{array}{c}\text { Kelas } \\
\text { Klasifikasi }\end{array}$} \\
\cline { 2 - 10 } & $\mathbf{1}$ & $\mathbf{2}$ & $\mathbf{3}$ & $\mathbf{4}$ & $\mathbf{1}$ & $\mathbf{2}$ & $\mathbf{3}$ & $\mathbf{4}$ & B \\
\hline 73 & MAHASISWA 211 & 3,48 & 2,90 & 3,53 & 3,58 & 21 & 24 & 20 & 24 & B \\
98 & MAHASISWA 23 & 2,57 & 3,17 & 3,02 & 3,33 & 21 & 21 & 23 & 24 & A \\
38 & MAHASISWA 219 & 2,43 & 2,55 & 2,64 & 3,05 & 21 & 19 & 22 & 21 & B \\
8 & MAHASISWA 11 & 2,71 & 1,50 & 2,94 & 2,45 & 21 & 21 & 16 & 20 & B \\
25 & MAHASISWA 201 & 2,86 & 2,93 & 3,65 & 3,31 & 21 & 21 & 24 & 24 & B \\
$\ldots$ & $\ldots$ & $\ldots$ & $\ldots$ & $\ldots$ & $\ldots$ & $\ldots$ & $\ldots$ & $\ldots$ & $\ldots$ & $\ldots$ \\
130 & MAHASISWA 233 & 2,36 & 1,78 & 3,03 & 2,75 & 21 & 18 & 15 & 24 & B \\
\hline
\end{tabular}

Selanjutnya dilakukan perhitungan algoritma CART pada boosting 1 dan didapatkan pohon keputusan boosting 1 . Kemudian dilakukan pengujian data training awal terhadap pohon keputusan yang dihasilkan algoritma CART pada boosting 1 . Hasil klasifikasi data training pada boosting 1 dapat dilihat pada Tabel 7.

Tabel 7. Hasil klasifikasi data training dengan menggunakan algoritma CART pada boosting 1

\begin{tabular}{|c|c|c|c|c|c|c|c|c|c|c|c|}
\hline \multirow{2}{*}{ No } & \multirow{2}{*}{ NIM } & \multicolumn{4}{|c|}{ IP Semester } & \multicolumn{4}{|c|}{ SKS Semester } & \multirow{2}{*}{$\begin{array}{c}\text { Kelas } \\
\text { Aktual }\end{array}$} & \multirow{2}{*}{$\begin{array}{c}\text { Prediksi } \\
\text { Kelas }\end{array}$} \\
\hline & & 1 & 2 & 3 & 4 & 1 & 2 & 3 & 4 & & \\
\hline 1 & MAHASISWA 1 & 2,79 & 2,98 & 3,48 & 3,00 & 21 & 21 & 21 & 24 & B & B \\
\hline 2 & MAHASISWA 2 & 2,79 & 2,55 & 3,71 & 3,23 & 21 & 21 & 19 & 24 & B & B \\
\hline 3 & MAHASISWA 3 & 2,36 & 1,17 & 1,65 & 2,91 & 21 & 18 & 13 & 16 & B & B \\
\hline$\ldots$ & $\ldots$ & .. & $\ldots$ & $\ldots$ & $\ldots$ & $\ldots$ & $\ldots$ & $\ldots$ & .. & .. & .. \\
\hline 146 & MAHASISWA 11 & 3,30 & 2,78 & 3,25 & 3,56 & 22 & 18 & 14 & 17 & B & B \\
\hline
\end{tabular}


Setelah didapatkan hasil pengujian data training. Kemudian menghitung nilai error $\left(\varepsilon_{t}\right)$ dari hasil prediksi kelas yang tidak sama dengna kelas aktual. Hasil pengujian data training menggunakan hasil algoritma CART pada boosting 1 terdapat 42 data yang berbeda.

$\varepsilon_{t}=\frac{42}{146}=0,287671$

Kemudian menemukan nilai Alpha $\left(\alpha_{\mathrm{t}}\right)$ pada boosting 1

$\alpha_{\mathrm{t}}=\frac{1}{2} \ln \left(\frac{1-0,287671}{0,287671}\right)=0,453361$

Setelah mendapatkan nilai Alpha $\left(\alpha_{\mathrm{t}}\right)$ pada boosting 1, kemudian memperbarui bobot dari masing-masing data pada data training dengan persamaan berikut.

$D_{t+1}(i)=\frac{D_{t}(i)}{z_{t}} \times\left\{\begin{array}{l}\exp \left(-\alpha_{t}\right) \text { if } h_{t}\left(x_{i}\right)=y_{i} \\ \exp \left(\alpha_{t}\right) \text { if } h_{t}\left(x_{i}\right) \neq y_{i}\end{array}\right.$

Pembaruan bobot data training dapat dilihat pada Tabel 8.

Tabel 8. Pembaruan bobot setiap data pada data training setelah boosting 1

\begin{tabular}{|c|c|c|c|c|c|c|c|c|c|c|c|}
\hline \multirow{2}{*}{ No } & \multirow{2}{*}{ NIM } & \multicolumn{4}{|c|}{ IP Semester } & \multicolumn{4}{|c|}{ SKS Semester } & \multirow{2}{*}{$D_{t}(i)$} & \multirow{2}{*}{$D_{t+1}(i)$} \\
\hline & & 1 & 2 & 3 & 4 & 1 & 2 & 3 & 4 & & \\
\hline 1 & MAHASISWA 1 & 2,79 & 2,98 & 3,48 & 3,00 & 21 & 21 & 21 & 24 & 0,006849 & 0,004808 \\
\hline 2 & MAHASISWA 2 & 2,79 & 2,55 & 3,71 & 3,23 & 21 & 21 & 19 & 24 & 0,006849 & 0,004808 \\
\hline 3 & MAHASISWA 3 & 2,36 & 1,17 & 1,65 & 2,91 & 21 & 18 & 13 & 16 & 0,006849 & 0,004808 \\
\hline$\ldots$ & MAU CICW 11 & & & & & & 10 & & & & \\
\hline 146 & MAHASISWA 11 & 3,30 & 2,78 & 3,25 & 3,56 & 22 & 18 & 14 & 17 & 0,006849 & 0,004808 \\
\hline
\end{tabular}

Kemudian dilakukan pengambilan data secara acak untuk menjadi boosting 2 yang diambil dari data training namun data yang memiliki bobot lebih besar memiliki kemungkinan terpilih lebih besar pula.

Selanjutnya mengulangi proses yang sama seperti boosting 1 sebanyak 10 boosting sehingga didapatkan 10 pohon keputusan yang dihasilkan dari algoritma CART dan 10 nilai alpha yang dihasilkan dari masing-masing pengujian data training pada setiap boosting. Setelah didapatkan 10 boosting, maka akan dilakukan pengujian dengan menggunakan data testing terhadap setiap algoritma CART pada masing-masing boosting yang telah ditemukan. Hasil pengujian data testing pada algoritma CART dengan teknik boosting dapat dilihat pada Tabel 9.

Tabel 9. Hasil pengujian data testing pada algoritma CART dengan teknik boosting

\begin{tabular}{cccccccccccc}
\hline \multirow{2}{*}{ No } & \multirow{2}{*}{ NIM } & $\mathbf{1}$ & $\mathbf{2}$ & $\mathbf{3}$ & $\mathbf{4}$ & $\mathbf{5}$ & $\mathbf{6}$ & $\mathbf{7}$ & $\mathbf{8}$ & $\mathbf{9}$ & $\mathbf{1 0}$ \\
\hline 1 & MAHASISWA 3 & B & B & B & A & B & B & B & B & B & B \\
2 & MAHASISWA 4 & B & B & B & A & B & B & B & B & B & B \\
3 & MAHASISWA 6 & B & B & B & A & B & B & B & B & B & B \\
$\ldots$ & $\ldots$ & $\ldots$ & $\ldots$ & $\ldots$ & $\ldots$ & $\ldots$ & $\ldots$ & $\ldots$ & $\ldots$ & $\ldots$ & $\ldots$ \\
49 & MAHASISWA 214 & A & A & A & A & A & A & A & B & B & A \\
\hline
\end{tabular}

Klasifikasi akhir pada teknik boosting menggunakan persamaan berikut.

$\mathrm{H}(\mathrm{x})=\operatorname{sign}\left(\sum_{t=1}^{T} \alpha_{t} h_{t}(x)\right)$

Klasifikasi yang menghasilkan A bernilai postif dan B bernilai negatif. Kemudian dikalikan dengan nilai alpha dari masing-masing boosting. Kemudian menjumlahkan semua hasil perkalian tersebut. Jika hasil akhir $\mathrm{H}(\mathrm{x})$ bernilai positif maka klasifikasi akhir bernilai A, jika hasil akhir $\mathrm{H}(\mathrm{x})$ bernilai negatif maka klasifikasi akhir bernilai $\mathrm{B}$. Klasifikasi akhir pada Boosting dapat dilihat pada Tabel 10. 
Tabel 12. Klasifikasi akhir algoritma CART dengan teknik boosting

\begin{tabular}{|c|c|c|c|c|c|c|c|c|c|c|c|c|c|}
\hline \multirow{2}{*}{ No } & \multirow{2}{*}{ NIM } & \multicolumn{10}{|c|}{$\alpha_{t} h_{t}(x)$} & \multirow{2}{*}{$\mathbf{H}(\mathbf{x})$} & \multirow{2}{*}{$\begin{array}{c}\text { Kelas } \\
\text { Prediksi } \\
\text { Boosting }\end{array}$} \\
\hline & & 1 & 2 & 3 & 4 & 5 & 6 & 7 & 8 & 9 & 10 & & \\
\hline 1 & $\begin{array}{c}\text { MAHASIS } \\
\text { WA3 }\end{array}$ & $-0,4534$ & $-0,6762$ & $-0,3883$ & 0,5585 & $-0,5771$ & $-0,6762$ & $-0,6555$ & $-0,4042$ & $-0,5771$ & $-0,4534$ & $-4,30278$ & B \\
\hline 2 & $\begin{array}{c}\text { MAHASIS } \\
\text { WA4 }\end{array}$ & $-0,4534$ & $-0,6762$ & $-0,3883$ & 0,5585 & $-0,5771$ & $-0,6762$ & $-0,6555$ & $-0,4042$ & $-0,5771$ & $-0,4534$ & $-4,30278$ & B \\
\hline 3 & $\begin{array}{c}\text { MAHASIS } \\
\text { WA6 }\end{array}$ & $-0,4534$ & $-0,6762$ & $-0,3883$ & 0,5585 & $-0,5771$ & $-0,6762$ & $-0,6555$ & $-0,4042$ & $-0,5771$ & $-0,4534$ & $-4,30278$ & B \\
\hline 4 & $\begin{array}{c}\text { MAHASIS } \\
\text { WA8 }\end{array}$ & $-0,4534$ & $-0,6762$ & $-0,3883$ & $-0,5585$ & $-0,5771$ & $-0,6762$ & $-0,6555$ & $-0,4042$ & $-0,5771$ & 0,4534 & $-4,51302$ & B \\
\hline 5 & $\begin{array}{l}\text { MAHASIS } \\
\text { WA11 }\end{array}$ & $-0,4534$ & $-0,6762$ & $-0,3883$ & 0,5585 & 0,5771 & $-0,6762$ & 0,6555 & $-0,4042$ & $-0,5771$ & 0,4534 & $-0,93093$ & B \\
\hline$\cdots$ & $\ldots$ & $\cdots$ & $\cdots$ & $\cdots$ & $\cdots$ & $\cdots$ & $\cdots$ & $\cdots$ & $\cdots$ & $\cdots$ & $\cdots \cdot$ & $\cdots$ & $\cdots$ \\
\hline 49 & $\begin{array}{c}\text { MAHASIS } \\
\text { WA214 }\end{array}$ & 0,4534 & 0,6762 & 0,3883 & 0,5585 & 0,5771 & 0,6762 & 0,6555 & $-0,4042$ & $-0,5771$ & 0,4534 & 3,457103 & A \\
\hline
\end{tabular}

\subsection{Evaluation}

Evaluation dilakukan dengan menggunakan metode confusion matix. Berikut ini confusion matrix dari hasil klasifikasi pada data testing dapat dilihat pada Tabel 11.

Tabel 11. Confusion matrix hasil klasifikasi pada data testing

\begin{tabular}{l|cccc}
\hline & TP & FN & FP & TN \\
\hline Algoritma CART & 10 & 6 & 4 & 29 \\
Algoritma CART dengan Teknik Bagging & 10 & 6 & 3 & 30 \\
Algoritma CART dengan Teknik Boosting & 13 & 3 & 3 & 30 \\
\hline
\end{tabular}

Perbandingan hasil evaluasi dari algoritma $C A R T$, algoritma $C A R T$ dengan teknik bagging, dan algoritma CART dengan teknik boosting menggunakan confusion matrix dapat dilihat pada Gambar 5.

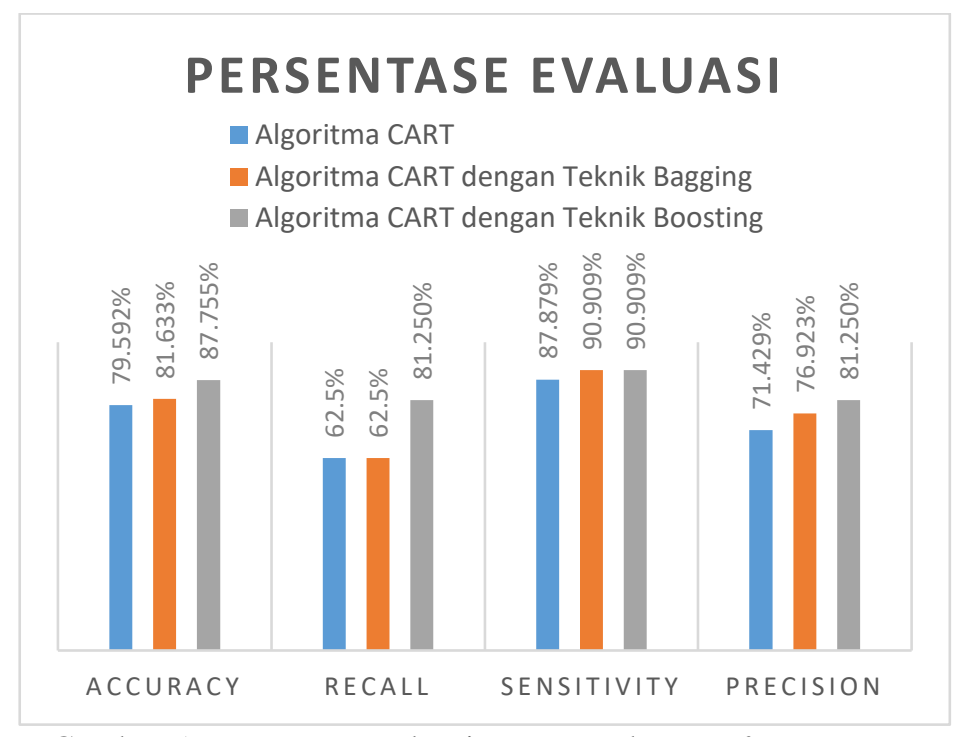

Gambar 5. Persentase evaluasi menggunakan confusion matrix 


\section{KESIMPULAN}

Nilai accuracy keseluruhan klasifikasi masa studi mahasiswa menggunakan algoritma CART sebesar 79,592\%, algoritma CART dengan teknik bagging 81,633\%, dan algoritma CART dengan teknik boosting $87,755 \%$. Nilai Accuracy untuk kelas minoritas yaitu kelas "A" atau "Tepat Waktu" dilihat dari nilai recall, model klasifikasi algoritma CART dengan teknik boosting merupakan model klasifikasi yang paling baik di antara tiga model klasifikasi yang diteliti untuk mengatasi kelas tidak seimbang yaitu sebesar $81,25 \%$.

\section{DAFTAR PUSTAKA}

Alfaro, E., Gámez, M., \& García, N. (2013). adabag: An R Package for Classi cation with Boosting and Bagging. Journal of Statistical Software, 54(2), 1-35.

Bisri, A., \& Wahono, R. S. (2015). Penerapan Adaboost untuk penyelesaian ketidakseimbangan kelas pada Penentuan kelulusan mahasiswa dengan metode Decision Tree. Journal of Intelligent Systems, 1(1), 27-32.

Chao, W.-L., Liu, J.-Z., \& Ding, J.-J. (2013). Facial age estimation based on label-sensitive learning and age-oriented regression. Pattern Recognition, 46(3), 628-641.

Faisal, M. R. (2016). Data Scienci Klasifikasi dengan Bahasa Pemrograman. Banjarmasin: INDC.

Kotsiantis, S. B., \& Pintelas, P. E. (2009). Selective costing ensemble for handling imbalanced data sets. International Journal of Hybrid Intelligent Systems, 6(3), 123-133.

Kotsiantis, S., Kanellopoulos, D., \& Pintelas, P. (2006). Handling imbalanced datasets: A review. GESTS International Transactions on Computer Science and Engineering, 30(1), 25-36.

Lewis, R. J. (2000). An introduction to classification and regression tree (CART) analysis. In Annual meeting of the society for academic emergency medicine in San Francisco (Vol. 14).

Liang, G., \& Zhang, C. (2011). An Empirical Study of Bagging Predictors on Medical Data. In Proceedings of the Ninth Australasian Data Mining Conference (Vol. 121, pp. 31-40).

Nasution, N., Djahara, K., \& Zamsuri, A. (2015). Evaluasi Kinerja Akademik Mahasiswa Menggunakan Algoritma Naïve Bayes (Studi Kasus: Fasilkom Unilak). Digital Zone: Jurnal Teknologi Informasi Dan Komunikasi, 6(2), 1-11.

Prasetio, R. T., \& Pratiwi, P. (2015). Penerapan Teknik Bagging pada Algoritma Klasifiikasi untuk Mengatasi Ketidakseimbangan Kelas Dataset Medis. Jurnal Informatika, 2(2), 395-403.

Salmu, S., \& Solichin, A. (2017). Prediksi Tingkat Kelulusan Mahasiswa Tepat Waktu Menggunakan Naïve Bayes : Studi Kasus UIN Syarif Hidayatullah Jakarta. In Prosiding Seminar Nasional Multidisiplin Ilmu (Vol. 22).

Susanto, S., \& Suryadi, D. (2010). Pengantar Data Mining. Yogyakarta: Penerbit Andi.

Timofeev, R. (2004). Classification an Regresion Trees Theory and Application. Humboldt University.

Weiss, G. M., McCarthy, K., \& Zabar, B. (2007). Cost- Sensitive Learning vs. Sampling: Which is Best for Handling Unbalanced Classes with Unequal Error Costs? DMIN, 7, 35-41.

Yamasari, Y., Nugroho, S. M., Suyatno, D. F., \& Purnomo, M. H. (2017). Meta-Algoritme Adaptive Boosting untuk Meningkatkan Kinerja Metode Klasifikasi pada Prestasi Belajar Mahasiswa. Jurnal Nasional Teknik Elektro Dan Teknologi Informasi (JNTETI), 6(3), 333-341.

Yap, B. W., Rani, K. A., Rahman, H. A. A., Fong, S., Khairudin, Z., \& Abdullah, N. N. (2014). An Application of Oversampling, Undersampling, Bagging and Boosting in Handling Imbalanced Datasets. In Proceedings of the First International Conference on Advanced Data and Information Engineering (DaEng-2013) (pp. 13-22). Singapore: Spriger. 